\title{
WORKING CAPITAL MANAGEMENT AND CORPORATE PROFITABILITY: EMPIRICAL EVIDENCE FROM VIETNAM
}

\author{
An Thanh Hong NGUYEN*, Tuan Van NGUYEN** \\ University of DaLat, Faculty of Economics and Business Administration, DaLat, Lamdong, VIETNAM \\ *e-mail: annth@dlu.edu.vn \\ **e-mail: tuannv@dlu.edu.vn
}

\begin{abstract}
This paper examines the relationship between working capital management and corporate profitability of Vietnamese listed firms. We propose a different interpretation of the empirical evidence that takes into account the dependency of collection and payment decisions. This helps establish the causal relationship between working capital management and firm profitability, which made the interpretation of the empirical results more meaningful and consistent with the real practice of firms. The analysis results based on a sample of 374 Vietnamese listed firms in the period from 2008 to 2014 show that working capital management positively affects the performance of Vietnamese listed companies. However, the results also indicate that Vietnamese firms do not intentionally use trade credit policy to enhance firms' performance and the observed relationship between trade credit and profitability, though significant, is just by coincidence.
\end{abstract}

Keywords: working capital management, cash conversion cycle, profitability, Vietnam.

JEL: G3, G31, G32.

\section{$1 \quad$ Introduction ${ }^{1}$}

The management of short-term assets and liabilities ensures the stability of firms' daily operation and financial activities. Firstly, working capital can help as it increases the operating efficiency of firms through sales and hence the profits (Petersen and Rajan, 1997). Secondly, working capital management is important with regard to its direct effect on firm liquidity (Opler, et al., 1999). Therefore, it follows that the efficient management of working capital is relevant and is a key part of the overall strategy of any company to create shareholder value (Shin and Soenen, 1998).

The importance of working capital management is also reflected by the sheer amount of research in the finance literature. A great deal of research has been done on the effects of various aspects of working capital management on firms' performance in different countries in the world, such as America (Jose, Lancaster and Stevens, 1996; Shin and Soen-

\footnotetext{
1 Acknowledgments: This research is funded by Vietnam National Foundation for Science and Technology Development (NAFOSTED) under grant number 502.02-2015.26. We would like to thank Ms. Truong Huyen Trang and Mr. Vu Minh Quang for their assistance in the data collecting process.
}

en, 1998), Japan and Taiwan (Wang, 2002), Belgium (Deloof, 2003), Greece (Lazaridis and Tryfonidis, 2006), Pakistan (Raheman and Nasr, 2007), Jordan (Abusayed, 2012), Brazil (Almeida and Eid, 2014), and UK (Barnos-Caballero, García-Teruel and Martinez-Solano, 2014), to name a few.

In general, empirical studies provided evidence that tighter working capital management positively affects firm profitability (Knauer and Wohrmann, 2013). However, the direction and significance of the effect of different components of working capital are not conclusive, which called for more empirical evidence from more countries and in different contexts.

Another shortcoming of previous studies on this topic is that they do not formally recognize the dependency among inventory, payment, and collection decisions, which is proved theoretically by Kim and Chung (1990). This not only makes the regression results biased and inconsistent but also led to confusing and, sometimes, meaningless interpretation of the results.

In this paper, we examined the relationship between working capital management and firm profitability in the context of the Vietnamese market. Based on previous literature on the positive effect of working capital management on firms' profitability, we hy- 
pothesize that working capital management also helps improve the Vietnamese firms' profitability. To test the hypothesis, we analyze the cash conversion cycle data of 374 listed Vietnamese companies on the Ho Chi Minh City Stock Exchange (HOSE), Hanoi Stock Exchange (HNX), and UPCOM Stock Exchange for the period 2008 - 2014. The results generally confirmed the hypothesis, that better working capital management positively affects the performance of Vietnamese companies.

However, detailed investigation into the nature of these benefits shows quite interesting results. After the control for the effect of dependency among components of cash conversion cycle, the evidence indicates that speeding up the collection and payment cycle seems to improve the firms' performance. Moreover, a larger stock of inventory, that is, lower supplying costs and price fluctuations, also has a positive effect on the firms' performance in Vietnam. This indicates that the benefits of working capital management for the Vietnamese listed firms seem to come mainly from the improvements in operational efficiency rather than economizing on internal financing sources.

This research contributes to the literature on working capital management in two folds. Firstly, it provides additional empirical evidence on the effect of working capital management on the firms' financial performance in the context of emerging economies, particularly Vietnam in this case. Secondly, this paper formally recognizes the dependency of the collection, payment, and inventory decisions into the empirical analyses and interpretations of the results. This helps produce consistent estimates and make the interpretation of the results more meaningful.

The research paper was structured as follow. The next section provided a brief review of the existing literature, based on which the hypotheses have been developed. The third and the fourth section described the data and the model. The next section presented and discussed the results. The final section presented the conclusions and implications for future research.

\section{Related literature and hypothesis develop- ment}

\subsection{Literature review}

By definition, working capital is the difference between current assets and current liabilities. The components of working capital were cash, accounts receivable, inventories, accounts payable, current debt, and the current portion of long-term debt (Mun and Jang, 2015). The first paper that recognizes the potential effect of working capital management on firms' profitability and calls for detailed research on this topic is by Sagan (1955). Ever since, research on the effect of various aspects of working capital has been done extensively. In particular, there is a large stream of literature on trade credit (both receivables and payables). Trade credits are private loans extended among trade partners to facilitate trades.

By definition, granting trade credit might increase a firm's financial performance, because it serves as an effective price discount (Petersen and Rajan, 1997); thus, reducing the costs of goods sold and improve firms' profits. Moreover, trade credit also encouraged customers to stock up more inventory at times of low demand (Emery, 1987). From another point of view, researchers also show that firms normally consider trade credits as a tool for reducing information asymmetry between customers and suppliers (Lee and Stowe, 1993); thus, help build a strong long-term mutual benefit relationship (Smith and Smith, 1999).

Research into inventories has also attracted much attention; however, the results are still yet conclusive. Blinder and Maccini (1991) suggest that larger inventories could reduce supply costs and price fluctuations and prevent interruptions in the production process and loss of business due to scarcity of products. They also allowed better services for firms' customers and avoided high production costs arising from high fluctuations in production (Schiff and Lieber, 1974). However, many studies show that investment in working capital is not without costs. Keeping stock available supposes costs such as warehouse rent, insurance, and security expenses, 
which tend to rise as the level of inventory increases (Kim \& Chung, 1990).

Instead of using monetary amount in measuring working capital components, some recent studies take another approach by utilizing the cash conversion cycle, calculated from inventory turnover period, account receivables collection period, and account payables disbursement period, to measure the practice of working capital management. Shin and Soenen (1998) investigate the relationship between the cash conversion cycle measure and corporate profitability. For a large sample of listed American firms for the period 1975 - 1994, they find a strong negative relation. This result indicates that managers can create value for their shareholders by reducing the cash conversion cycle to a reasonable minimum.

Deloof (2003) conducts a similar study with Belgium firms for the period 1992 - 1996 and find that managers could increase corporate profitability by reducing the number of day accounts receivable and inventories. For Finnish firms, Enqvist, Graham, and Nikkinen (2014) discover a negative relationship between cash conversion cycle and firm profitability. In term of each component of cash conversion cycle, they find that firm's profitability has a negative relationship with inventory turnover cycle, account payables disbursement cycle, and account receivables collection cycle. Similar results are found in other countries, such as Spain (García-Teruel and Martínez-Solano, 2007), Jordan (Abusayed, 2012), and America (Gill, Biger and Mathur, 2010). However, in term of account payable disbursement cycle, the results for Greece are quite different. Using a sample of 524 firm-years, Lazaridis and Tryfonidis (2006) show that the relationship between the account payable cycle and firm profitability is positive. This is contrary to the findings in the other countries.

There are two caveats that we can see from the previous literature. Firstly, the research results on the effect of working capital management on firms' financial performance are mainly from the developed Western countries and the results are still inconclusive. This opens the door for more empirical research in different countries and contexts, especially the developing Asian countries. This is hoped to provide new insights into the existing literature. Secondly, previous literature largely ignores the interdependency among different components of working capital. Kim and Chung (1990) have proved theoretically that these items are, in fact, interconnected and should be treated simultaneously (e.g., the credit policy of a company influenced its sales and, at the same time, the level of inventories and the use of trade credit). Researching into different items of working capital without controlling for this relationship, therefore, would bias empirical estimates and lead to misleading conclusions and interpretations of results.

Following up on these two critiques, this research aims at examining the empirical relationship between working capital management and firms' performance in the context of Vietnam and proposes possible explanations for the nature of the relationship, taking the dependency nature of the three working capital components into account. Just as other developing nations, Vietnamese financial markets are characterized as less developed and the main source of funds, especially working capital, are internally financed (Nguyen and Nguyen, 2018; IMF, 2017). Thus, working capital management is of prime importance to firms. The results of this research will provide insights into how firms manage working capital and its effect on firms' performance in this particular context and contribution to the literature on working capital management, as a whole.

\subsection{Hypothesis development}

The cash conversion cycle (CCC), a popular measure of working capital management, has been widely used in recent literature (see for example Deloof, 2003; Gill, Biger and Mathur, 2010). The CCC, measured in days, measures the length of time between a company's expenditure for the procurement of raw materials and the collection of sales of finished goods. In line with the previous studies and to facilitate comparison, we use CCC as our measure of working capital management in this study.

Previous studies discover a negative relationship between profitability and the CCC in different contexts, such as America (Jose, Lancaster and Stevens, 1996; Shin and Soenen, 1998), Japan and Taiwan 
(Wang, 2002), Belgium (Deloof, 2003), Greece (Lazaridis and Tryfonidis, 2006), Pakistan (Raheman and Nasr, 2007), Jordan (Abusayed, 2012), Brazil (Almeida \& Eid, 2014), and UK (Barnos-Caballero, García-Teruel and Martinez-Solano, 2014), to name a few. Based on previous literature, we also expect a negative relationship between the cash conversion cycle and corporate profitability for the Vietnamese listed firms:

Hypothesis 1: There is a negative relationship between the cash conversion cycle and profitability.

To the extent that the relationship between CCC and firms' profitability were, in fact, negative, a natural following up question would be what the nature of this relationship is. To account for the nature of this relationship, there are two main lines of explanations. On the one hand, some researchers argue that efficient working capital management practices are aimed to shorten the CCC to optimize to levels that best suits the requirements of the specific company (Hager, 1976). This improves operational efficiency by reducing purchasing costs (Peter and Rajan, 1997), boosting demand (Emery, 1987), and strengthen the long-term mutual benefit relationship between partners (Lee and Stowe, 1993; Smith and Smith, 1998); and thus, would improve firms' profitability. Therefore, previous researchers propose a negative relationship between the cash conversion cycle and firms' performance.

On the other hand, some studies argue that working capital management can improve firms' performance via the financing channel. Based on the pecking order theory by Myers and Majluf (1984), researchers argue that in financial markets with high information asymmetry, firms tend to prefer internal sources of fund. As economizing on working capital may reduce the need for external, and usually more expensive, sources of fund, it follows that firms' efficient working capital management would positively affect Vietnamese firms' performance, that is, there is a negative relationship between cash conversion cycle and firms' performance (Almeida and Eid, 2014).

To make a prediction regarding the possible origin of benefits from working capital management, we need to look at how firms execute their working capital management policy; in this case, at the rela- tionship between the three components of $\mathrm{CCC}$ with firms' performance. The CCC had three components; account payable deferral period, accounts receivable conversion period, and inventories conversion period. A firm could minimize its $\mathrm{CCC}$ by optimizing these three components. However, as pointed out by Kim and Chung (1990), decisions on the three components of $\mathrm{CCC}$, by definition, are interdependent. Thus, we argue that we need to consider the relationship between the three components of CCC with firms' performance simultaneously in order to come to a rigorous explanation. Thus, we argue that if firms, in fact, manage their working capital for financing reasons, we would expect them to apply the principle of speeding up cash collections, slowing down cash disbursements, and minimizing inventories at the same time.

Operating with lean inventories, collect their receivables quickly, and delay payments to suppliers helped retain the firms' short-term capital, which reduces the need for external, and expensive, funds. If firms intentionally exercise their working capital management policy aiming at reducing the need for external funds, three hypotheses with regard to the relationship between the components of $\mathrm{CCC}$ with firms' profitability need to be confirmed:

Hypothesis 2: There is a positive relationship between the payables deferral period and profitability.

Hypothesis 3: There is a negative relationship between the receivables conversion period and profitability.

Hypothesis 4: There is a negative relationship between the inventory conversion period and profitability.

\section{$3 \quad$ Data and model specification}

\subsection{Data and variable description}

The firm-level data used in this paper consisted of information from financial reports of 374 listed companies on the HSX, HNX, and UPCOM exchanges with full required data between the years 2008 and 2014. The final sample consisted of 1136 firm-year observations. Following Shin and Soenen (1998); Deloof (2003); and Lazardis and Tryfonidis 
(2006), we exclude the financial firms from our dataset. As indicated above, our view of efficient working capital management is based on the concept of cash conversion cycle (CCC), defined as:

CCC

$=$ (No. of days Account Receivable

+ No. of days Inventorys)

- (No. of days Account Payable)

The three components of CCC are estimated as follows:

No. of days Account Receivable

$$
=\frac{\text { Account Receivables }}{\text { Sales }} \times 365
$$

No. of days Inventory

$$
=\frac{\text { Inventories }}{\text { Cost of Good Sold }} \times 365
$$

No. of days Account Payable

$$
=\frac{\text { Account Payables }}{\text { Sales }} \times 365
$$

Following Jose, Lancaster, and Stevens (1996); Wang (2002); Garcia-Teruel and Martinez-Solano (2007), we use the return on assets (ROA), measured as the ratio of net income to total assets, as a proxy for corporate profitability. For the robust test, we utilize an alternative measure of profitability, gross operating income (GOI), calculated as the ratio of sales (adjusted for cost of goods sold) to the difference between total assets and financial assets. While ROA could be considered as an overall indicator of profitability, GOI measures the operational performance. The use of two different measures of corporate performance provides a more diverse view of the topic as well as a cross-check for the results. We include several control variables known to affect firm profitability in the models to be estimated. In particular, we control for company size (natural logarithm of sales), current ratio (current assets/current liabilities), and debt ratio (total debt/total assets) (see e.g., Deloof, 2003; Lazaridis

\begin{tabular}{|c|c|c|c|c|c|}
\hline Variables & Code & Mean & Std Dev & Min & Max \\
\hline \multicolumn{6}{|l|}{ Working Capital Management } \\
\hline Cash Conversion Cycle & $\mathrm{CCC}$ & 170.367 & 304.448 & -1149.410 & 5587.016 \\
\hline Account Payable & APP & 57.764 & 89.396 & 0 & 1916.956 \\
\hline Account receivable & $\mathrm{ACP}$ & 86.945 & 99.182 & 0 & 998.0 \\
\hline Inventory & ICP & 141.186 & 278.823 & 0 & 5436.657 \\
\hline \multicolumn{6}{|l|}{ Profitability measures } \\
\hline Return on Assets & ROA & 0.068 & 0.088 & -0.994 & 1.106 \\
\hline Gross Operating Income to non-financial assets & GOI & 0.226 & 0.168 & -3.172 & 1.101 \\
\hline \multicolumn{6}{|l|}{ Control variables } \\
\hline Current ratio & $\mathrm{CR}$ & 2.142 & 2.784 & 0.110 & 62.850 \\
\hline Sales & SIZE & 8.612 & 0.629 & 6.830 & 10.730 \\
\hline Debt & DR & 0.518 & 0.224 & 0.006 & 1.564 \\
\hline \multicolumn{6}{|c|}{$\begin{array}{l}\text { Notes: Descriptive statistics for firm-level variable for the Vietnamese firms from the years } 2008 \text { to } 2014 \text {, for a total of } \\
2618 \text { observations. ROA is return on assets; CCC is cash conversion cycle; ICP is inventory conversion period; APP is } \\
\text { account payable period; ACP is account receivable cash period; SIZE is natural logarithm of sales; DR is debt ratio; } \\
\text { and CR is current ratio. }\end{array}$} \\
\hline
\end{tabular}
and Tryfonidis, 2006).

Table 1. Descriptive statistics

Table 1 presents the descriptive statistics for the variables used in the empirical analyses. In detail, the average cash conversion cycle for the Vietnamese firms is 170.3 days, which is higher than the Finnish firms (108.8 days), the Spanish SMEs (76.3 days) and the large Belgian companies (44.5 days), but lower than the average CCC of listed companies on the Athens Stock Exchange (189 days) 
(see Deloof, 2003; Lazaridis and Tryfonidis, 2006; Garcia-Teruel and Martinez-Solano, 2007; Enqvist, Graham and Nikkinen, 2014). The average accounts payables deferral, average inventory, and accounts receivables conversion periods are 57.7 days, 141.2 days, and 86.9 days, respectively. The mean inventory for the Vietnamese companies is higher relative to the Finnish (117.6), U.S. (78) and Belgian (46.62) firms (see Enqvist, Graham and Nikkinen,
2014; Gill, Biger and Mathur, 2010; Deloof, 2003) but lower than the Greek firms (see Lazaridis and Tryfonidis, 2006). The data also reveal that the mean ROA of the Vietnamese firms is $6.8 \%$, which is lower than the average value of $8.4 \%$ for the Finnish firms (Enqvist, Graham and Nikkinen, 2014) or $7.9 \%$ for the Spanish SMEs (GarciaTeruel and Martinez-Solano, 2007).

Table 2. Correlations of ROA with key variables

\begin{tabular}{|l|l|l|l|l|l|l|l|l|}
\hline & \multicolumn{1}{|c|}{ ROA } & CCC & ICP & APP & ACP & SIZE & DR & CR \\
\hline ROA & 1 & & & & & & & \\
\hline CCC & $-0.1508^{*}$ & 1 & & & & & & \\
\hline ICP & $-0.1136^{*}$ & $0.9437^{*}$ & 1 & & & & & \\
\hline APP & $-0.1708^{*}$ & $0.1187^{*}$ & $0.2973^{*}$ & 1 & & & & \\
\hline ACP & $-0.2976^{*}$ & $0.5235^{*}$ & $0.3537^{*}$ & $0.4298^{*}$ & 1 & & & \\
\hline SIZE & $-0.0774^{*}$ & $0.0776^{*}$ & $0.0873^{*}$ & $0.0454^{*}$ & 0.0335 & 1 & & \\
\hline DR & $-0.4640^{*}$ & $0.0939^{*}$ & $0.1172^{*}$ & $0.1939^{*}$ & $0.1336^{*}$ & $0.2990^{*}$ & 1 & \\
\hline CR & $0.1710^{*}$ & 0.0242 & -0.0055 & $-0.0971^{*}$ & 0.0021 & $-0.1683^{*}$ & $-0.4975^{*}$ & 1 \\
\hline
\end{tabular}

Notes: Pearson correlation coefficients for key variables, for a total of 2618 observations. ROA is return on assets; CCC is cash conversion cycle; ICP is inventory conversion period; APP is account payable period; ACP is account receivable cash period; SIZE is natural logarithm of sales; DR is debt ratio; and CR is current ratio. * denotes the level of significance of 0.05 or above.

Table 3. Correlations of GOI with key variables

\begin{tabular}{|c|c|c|c|c|c|c|c|c|}
\hline & GOI & $\mathrm{CCC}$ & ICP & APP & $\mathrm{ACP}$ & SIZE & DR & $\mathrm{CR}$ \\
\hline GOI & 1 & & & & & & & \\
\hline $\mathrm{CCC}$ & $-0.2347^{*}$ & 1 & & & & & & \\
\hline ICP & $-0.1881 *$ & $0.9437^{*}$ & 1 & & & & & \\
\hline APP & $-0.2169 *$ & $0.1187^{*}$ & $0.2973 *$ & 1 & & & & \\
\hline $\mathrm{ACP}$ & $-0.3871^{*}$ & $0.5235^{*}$ & $0.3537^{*}$ & $0.4298 *$ & 1 & & & \\
\hline SIZE & $-0.1995^{*}$ & $0.0776^{*}$ & $0.0873^{*}$ & $0.0454^{*}$ & 0.0335 & 1 & & \\
\hline DR & $-0.3231 *$ & $0.0939 *$ & $0.1172 *$ & $0.1939 *$ & $0.1336^{*}$ & $0.2990^{*}$ & 1 & \\
\hline CR & $0.0644 *$ & 0.0242 & -0.0055 & $-0.0971^{*}$ & 0.0021 & $-0.1683^{*}$ & $-0.4975^{*}$ & 1 \\
\hline
\end{tabular}

The average value of gross operating income for the Vietnamese firms is $22.6 \%$. This is significantly lower than the value of $101 \%$ for the Finnish firms (Enqvist, Graham and Nikkinen, 2014) but higher than value of $12.2 \%$ for the Belgian firms (Deloof, 2003). In general, about $51.8 \%$ of the Vietnamese company's assets are financed with debt, which is roughly equal to the Finnish firms (55.3\%). 
However, the debt ratio of the Vietnamese firms has a high standard deviation (22.4\%) and the maximum figure is as high as $156.4 \%$. With regard to liquidity, the Vietnamese firms have an average current ratio of 2.1, which is better than the Finnish firms (1.6), but with a high standard deviation (2.8), which also is higher than that of the Finnish firms (0.6) (Enqvist, Graham and Nikkinen, 2014).

Table 2 and Table 3 present the pairwise correlations between ROA and GOI with other variables used in this study. The results show that there is a significant negative relationship between $\mathrm{CCC}$ and the two measures of corporate performance, ROA, and GOI. The correlations between the components of CCC and both ROA and GOI are also significantly negative. In particular, inventory generally shows negative correlations with the two profitability measures, which means that stocking up inventories generally associates with less profitability. The negative correlations between APP and ROA and GOI imply that less profitable firms tend to delay paying their bills. Likewise, account receivable has a negative correlation with profitability. The control variables, debt ratio and the logarithm of sales are negatively correlated with the two measures of profitability, while current ratio is positively correlated with the two measures of profitability.

\subsection{Model specification}

To test the first hypothesis, we regress the corporate profitability measures, which are return on asset (ROA) and gross operating profit (GOI), against cash conversion cycle (CCC). Additional variables are also added to the model to control for other potential influences on the performance of the firm. Specifically, these variables are logarithms of sales (SIZE), debt ratio (DR), and current ratio (CR).

Therefore, we estimate the model:

$$
\begin{aligned}
\text { Profitability }_{i t} & =\beta_{0}+\beta_{1} \mathrm{CCC}_{i t}+\beta_{2} \mathrm{CR}_{\mathrm{it}} \\
& +\beta_{3} \mathrm{DR}_{\mathrm{it}}+\beta_{4} \mathrm{SIZE}_{\mathrm{it}}+\mathrm{u}_{\mathrm{i}}+\varepsilon_{\mathrm{it}}
\end{aligned}
$$

As we are analyzing with panel data, we regress equation (5) with fixed effect and random effect and use the Hausman's test to identify the consistent and most effective model. We also make proper proce- dures to account for heteroskedasticity and clustering effect in the model.

To test for the rest three hypotheses, we re-use the above model as the basis to examine the effect of the three components of CCC on the two profitability measures, by substituting CCC with the account payable deferral period (APP), the account receivable conversion period (ACP), and the inventory conversion period (ICP). However, as pointed out theoretically by Kim and Chung (1990), the three components of CCC are inter-connected. Their highly significant positive correlation coefficients from Table 2 and 3 also confirm the remark. Due to this inter-relationship, regressing each individual component of CCC with firms' profitability without taking the other two into account will produce biased and inconsistent estimates. To remedy, we propose using $\mathrm{CCC}$ as a control variable. CCC, by definition, has a significant correlation with all three components; thus, it may help solve the problem. Thus, we estimate the models:

$$
\begin{aligned}
& \text { Profitability }_{\text {it }}=\beta_{0}+\beta_{1} \mathrm{APP}_{\text {it }}+\beta_{2} \mathrm{CR}_{\text {it }} \\
& +\beta_{3} \mathrm{DR}_{\mathrm{it}}+\beta_{4} \mathrm{SIZE}_{\mathrm{it}} \\
& +\beta_{5} \mathrm{CCC}_{\mathrm{it}}+\mathrm{u}_{\mathrm{i}}+\varepsilon_{\mathrm{it}} \\
& \text { Profitability }_{i t}=\beta_{0}+\beta_{1} \mathrm{ICP}_{i t}+\beta_{2} \mathrm{CR}_{\text {it }} \\
& +\beta_{3} \mathrm{DR}_{\mathrm{it}}+\beta_{4} \mathrm{SIZE}_{\mathrm{it}} \\
& +\beta_{5} \mathrm{CCC}_{\mathrm{it}}+\mathrm{u}_{\mathrm{i}}+\varepsilon_{\mathrm{it}} \\
& \text { Profitability }_{\text {it }}=\beta_{0}+\beta_{1} \mathrm{ACP}_{\text {it }}+\beta_{2} \mathrm{CR}_{\text {it }} \\
& +\beta_{3} \mathrm{DR}_{\mathrm{it}}+\beta_{4} \mathrm{SIZE}_{\mathrm{it}} \\
& +\beta_{5} \mathrm{CCC}_{i t}+\mathrm{u}_{\mathrm{i}}+\varepsilon_{\mathrm{it}}
\end{aligned}
$$

However, the specifications of equations (6), (7), and (8) may give rise to the multicollinearity problem. With reference to Table 2, we can see that the correlation between CCC and APP is 0.1187 , and the correlation between $\mathrm{CCC}$ and ACP is 0.5235 (corresponding to VIF of 1.05 and 1.40 , respectively), which are not serious.

However, the correlation between CCC and ICP is 0.9437 (corresponding to VIF of 9.24), which is high and indicates that multicollinearity might be a problem in equation (7). In our case, we have to consider the trade-off between the two problems: the first is the omitted variable problem, which will make the estimators inconsistent; and the second is the multicollinearity problem between CCC and ICP, which may invalidate our hypothesis test on 
the coefficient of ICP. As the omitted variable problem is a much more serious problem, we prioritize our tools at hand to solve this problem first (by adding $\mathrm{CCC}$ to the equations).

After solving the omitted variable problem, we still face the multicollinearity problem between CCC and ICP. This will inflate the variance of the regression coefficient of ICP, which may invalidate our test relating to the regression coefficients of ICP. However, in this particular context, even when the variance is inflated, the test results for the coefficient of ICP are still significant at 5\% (Table 4) and 10\% (Table 5). We think that these results, though not optimal, still yield some useful information about the relationship between CCC and ICP. This point of view is also supported by O'Brien (2007). We fully aware that multicollinearity is a problem in the model (7) and our solution is not the best. However, given the tools at hand, we think that this is a reasonable trade-off.

\section{$4 \quad$ Results and discussions}

Table 4 and Table 5 present the results of the regression models investigating the relationship between working capital management and corporate profitability. The cash conversion cycle and its three components are individually regressed against the two measures of profitability. The relevant measure of profitability is ROA in Table 4 and GOI in Table 5 . In both the tables, the results of four regression models are presented, corresponding to equation (5) in column (1), equation (6) in column (2), equation (7) in column (3), and equation (8) in column (4).

Table 4. The relation of ROA with working capital management

\begin{tabular}{|l|l|l|l|l|l|}
\hline $\begin{array}{c}\text { Coefficient } \\
\text { estimate }\end{array}$ & $\begin{array}{c}\text { Expected } \\
\text { sign }\end{array}$ & \multicolumn{1}{|c|}{$(1)$} & \multicolumn{1}{|c|}{$(2)$} & \multicolumn{1}{|c|}{$(4)$} \\
\hline Intercept & & $0.33890^{* * *}$ & $0.33276^{* * *}$ & $0.33405^{* * *}$ & $0.29582^{* * *}$ \\
\hline CCC & - & $-0.00002^{* * *}$ & $-0.00002^{* *}$ & $-0.00010^{* * *}$ & 0.000001 \\
\hline APP & + & & $-0.00003^{* *}$ & & \\
\hline ICP & - & & & $0.00009^{* *}$ & \\
\hline ACP & - & & & & $-0.00018^{* * *}$ \\
\hline SIZE & & -0.01763 & -0.01675 & -0.01684 & -0.01130 \\
\hline DR & & $-0.21730^{* * *}$ & $-0.21577^{* * *}$ & $-0.22121^{* * *}$ & $-0.21659^{* * *}$ \\
\hline CR & & $-0.00115^{*}$ & $-0.00132^{*}$ & -0.00082 & $-0.00140^{*}$ \\
\hline F-value & & 23.54 & 20.93 & 20.54 & 20.31 \\
\hline p-value & & 0.0000 & 0.0000 & 0.0000 & 0.0000 \\
\hline $\mathrm{N}$ & & 2618 & 2618 & 2618 & 2618 \\
\hline
\end{tabular}

Notes: Column (2), (3), (4), and (5) in the table report results from estimating the following regression models from the year 2008 to 2014 with 2618 observations of the following model, respectively:

$$
\begin{aligned}
& \text { Profitability }_{i t}=\beta_{0}+\beta_{1} \mathrm{CCC}_{i t}+\beta_{2} \mathrm{CR}_{\text {it }}+\beta_{3} \mathrm{DR}_{\mathrm{it}}+\beta_{4} \mathrm{SIZE}_{\mathrm{it}}+\mathrm{u}_{\mathrm{i}}+\varepsilon_{\mathrm{it}} \\
& \text { Profitability }{ }_{i t}=\beta_{0}+\beta_{1} \mathrm{APP}_{i t}+\beta_{2} \mathrm{CR}_{\text {it }}+\beta_{3} \mathrm{DR}_{\mathrm{it}}+\beta_{4} \mathrm{SIZE}_{\mathrm{it}}+\beta_{5} \mathrm{CCC}_{\mathrm{it}}+\mathrm{u}_{\mathrm{i}}+\varepsilon_{\text {it }} \\
& \text { Profitability }_{\text {it }}=\beta_{0}+\beta_{1} \mathrm{ICP}_{\text {it }}+\beta_{2} \mathrm{CR}_{\text {it }}+\beta_{3} \mathrm{DR}_{\text {it }}+\beta_{4} \mathrm{SIZE}_{\text {it }}+\beta_{5} \mathrm{CCC}_{\text {it }}+\mathrm{u}_{\mathrm{i}}+\varepsilon_{\mathrm{it}} \\
& \text { Profitability }_{\text {it }}=\beta_{0}+\beta_{1} \mathrm{ACP}_{\text {it }}+\beta_{2} \mathrm{CR}_{\text {it }}+\beta_{3} \mathrm{DR}_{\text {it }}+\beta_{4} \mathrm{SIZE}_{i \mathrm{t}}+\beta_{5} \mathrm{CCC}_{\mathrm{it}}+\mathrm{u}_{\mathrm{i}}+\varepsilon_{\mathrm{it}}
\end{aligned}
$$

where profitability is measured by return on assets (ROA); CCC is cash conversion cycle; ICP is inventory conversion period; APP is account payable period; ACP is account receivable cash period; SIZE is natural logarithm of sales; DR is debt ratio; and $\mathrm{CR}$ is current ratio. *, **, *** denotes the level of significance of $10 \%, 5 \%$, and $1 \%$, respectively.

The models are estimated using the panel data analysis techniques. The Breusch - Pagan LM test statistic is 1123.83 (pvalue $=0.0000)$, indicating that the random effect model is more efficient than the OLS model. The Hausman's test statistics is 16.79 ( $\mathrm{p}$-value $=0.0000)$, indicating that the fixed effect model is more efficient than the random effect model. Thus, the fixed effect model is chosen for analysis. Appropriate procedures are applied to resolve the heteroskedasticity and clustering problems. 
The results for equation (5), which analyses the relationship between CCC and profitability, are presented in column (1) in Table 4 and Table 5. The results in both tables show that there is a significant negative relationship between $\mathrm{CCC}$ and two measures of profitability, ROA and GOI. Therefore, hypothesis 1 , which states that there is a negative relationship between working capital management and firms' profitability, is confirmed. This result is consistent with previous studies (Deloof, 2003; Garcia-Teruel and Martinez-Solano, 2007; Lazaridis and Tryfonidis, 2006). This result implies that companies can increase their profitability by improving their working capital management efficiency, that is, by minimizing CCC.

Table 5. The relation of GOI with working capital management

\begin{tabular}{|l|l|l|l|l|l|}
\hline $\begin{array}{c}\text { Coefficient } \\
\text { estimate }\end{array}$ & $\begin{array}{c}\text { Expected } \\
\text { sign }\end{array}$ & \multicolumn{1}{|c|}{$(1)$} & \multicolumn{1}{|c|}{$(2)$} & \multicolumn{1}{|c|}{$(3)$} \\
\hline Intercept & & $0.85423^{* * *}$ & $0.8369^{* * *}$ & $0.84939^{* * *}$ & $0.79196^{* * *}$ \\
\hline CCC & - & $-0.00004^{* * *}$ & $-0.00003^{* * *}$ & $-0.00012^{* *}$ & -0.000001 \\
\hline APP & + & & $-0.00009^{* * *}$ & & \\
\hline ICP & - & & & $0.00009^{*}$ & \\
\hline ACP & - & & & & $-0.00026^{* * *}$ \\
\hline SIZE & & -0.05363 & -0.05117 & -0.05284 & -0.04448 \\
\hline DR & & $-0.29428^{* * *}$ & $-0.28996^{* * *}$ & $-0.29817^{* * *}$ & $-0.2932^{* * *}$ \\
\hline CR & & $-0.00327^{* * *}$ & $-0.00373^{* * *}$ & $-0.00294^{* *}$ & $-0.00362^{* * *}$ \\
\hline F-value & & 25.03 & 21.22 & 22.01 & 25.83 \\
\hline p-value & & 0.0000 & 0.0000 & 0.0000 & 0.0000 \\
\hline N & & 2618 & 2618 & 2618 & 2618 \\
\hline
\end{tabular}

Notes: Column (2), (3), (4), and (5) in the table report results from estimating the following regression models from the year 2008 to 2014 with 2618 observations of the following model, respectively:

$$
\begin{aligned}
& \text { Profitability }{ }_{i t}=\beta_{0}+\beta_{1} \mathrm{CCC}_{\mathrm{it}}+\beta_{2} \mathrm{CR}_{\mathrm{it}}+\beta_{3} \mathrm{DR}_{\mathrm{it}}+\beta_{4} \mathrm{SIZE}_{\mathrm{it}}+\mathrm{u}_{\mathrm{i}}+\varepsilon_{\mathrm{it}} \\
& \text { Profitability }_{i t}=\beta_{0}+\beta_{1} \mathrm{APP}_{\text {it }}+\beta_{2} \mathrm{CR}_{\mathrm{it}}+\beta_{3} \mathrm{DR}_{\mathrm{it}}+\beta_{4} \mathrm{SIZE}_{\mathrm{it}}+\beta_{5} \mathrm{CCC}_{\mathrm{it}}+\mathrm{u}_{\mathrm{i}}+\varepsilon_{\mathrm{it}} \\
& \text { Profitability }_{i t}=\beta_{0}+\beta_{1} \mathrm{ICP}_{\text {it }}+\beta_{2} \mathrm{CR}_{\text {it }}+\beta_{3} \mathrm{DR}_{\mathrm{it}}+\beta_{4} \mathrm{SIZE}_{\text {it }}+\beta_{5} \mathrm{CCC}_{\mathrm{it}}+\mathrm{u}_{\mathrm{i}}+\varepsilon_{\text {it }} \\
& \text { Profitability }{ }_{i t}=\beta_{0}+\beta_{1} \mathrm{ACP}_{i t}+\beta_{2} \mathrm{CR}_{\text {it }}+\beta_{3} \mathrm{DR}_{\mathrm{it}}+\beta_{4} \mathrm{SIZE}_{\mathrm{it}}+\beta_{5} \mathrm{CCC}_{\mathrm{it}}+\mathrm{u}_{\mathrm{i}}+\varepsilon_{\mathrm{it}}
\end{aligned}
$$

where profitability is measured by return on assets (ROA); CCC is cash conversion cycle; ICP is inventory conversion period; APP is account payable period; ACP is account receivable cash period; SIZE is natural logarithm of sales; DR is debt ratio; and CR is current ratio. *,**,*** denotes the level of significance of $10 \%, 5 \%$, and $1 \%$, respectively. The models are estimated using panel data analysis techniques. The Breusch - Pagan LM test statistic is 1123.83 (pvalue $=0.0000)$, indicating that the random effect model is more efficient than the OLS model. The Hausman's test statistics is 16.79 ( $\mathrm{p}$-value $=0.0000$ ), indicating that the fixed effect model is more efficient than the random effect model. Thus, the fixed effect model is chosen for analysis. Appropriate procedures are applied to resolve the heteroskedasticity and clustering problems.

The results for equation (6), which explores the relationship between account payable deferral period and profitability, are presented in column (2) in Table 4 and Table 5. The results show that there is a negative and significant relationship between account payable deferral period with both ROA and GOI, implying that a shorter account payable deferral period actually improves firms' profitability. This rejects hypothesis 2, which states that there is a negative relationship between account payable deferral period and firms' profitability. It can be inferred from the result that more profitable firms in Vietnam do not use trade credit as a source of short-term funds. This is consistent with the case of Finnish companies (Enqvist, Graham and Nikkinen, 2014), but contrasts with the Greek case (Lazaridis and Tryfonidis, 2006). 
The results for equation (7), which examines the relationship between inventory conversion period and profitability, are presented in column (3) in Table 4 and Table 5 . The results show that the relationship between inventory conversion period and profitability is positive and significant; thereby, rejecting hypothesis 3 . This means that piling up inventory will generally improve the profitability of firms. This result is contrary with some prior studies, such as Deloof (2003); Garcia-Teruel and Martinez-Solano (2007); and Enqvist, Graham, and Nikkinen (2014), but similar to some others, such as Lazaridis and Tryfonidis (2006).

Finally, results for equation (8), which examines the relationship between account receivable conversion period and profitability, are presented in column (4) in Table 4 and Table 5. The results show that there is a negative and significant relationship between the account receivable conversion period and both measures of firms' profitability. This evidence supports hypothesis 4, implying that reducing the average number of days it takes to collect receivables helps improve firms' profitability. Again, the result is consistent with some prior studies, such as Deloof (2003); Lazaridis and Tryfonidis (2006); and Garcia-Teruel and Martinez-Solano (2007), but differs from some others, such as Enqvist, Graham, and Nikkinen (2014). This also reconfirms the conclusion that the effect of different aspects of working capital management on profitability is not conclusive and depends on the context (Enqvist, Graham and Nikkinen, 2014).

While the results on each component of cash conversion cycle, that is, ACP, APP, and ICP, yield some useful information, we argue that the interpretation of results in this way will not be complete due to the inter-dependency of the three components. The above evidence shows that Vietnamese firms seem to be more profitable when they speed up the collection and payment process and maintain a large amount of inventory. This pattern is inconsistent with the view that firms regard working capital as an internal source of fund. In fact, it seems more likely that Vietnamese firms speed up their collection and payment cycle and stock a high amount of inventory to reduce supply costs and price fluctuations. This implies that Vietnamese firms seem to economize on working capital to improve their operational efficiency; and thus, their profitability.

\section{Conclusions}

This study examines the relationship between working capital management and corporate profitability in the context of Vietnam by using a sample of 374 listed companies from years 2008 to 2014. By taking the inter-dependency nature of the three components of cash conversion cycle into account, the research is expected to produce consistent estimates and more complete interpretations of the regression results. The results reveal two findings about the practice of the working capital management of the Vietnamese firms. Firstly, the research shows that better working capital management, represented by lower cash conversion cycle, helps improve firms' financial performance. Secondly, detailed analysis shows that the Vietnamese firms seem to be more profitable when they speed up the collection and payment process and maintain a large amount of inventory. Thus, it seems more likely that the Vietnamese firms speed up their collection and payment cycle and stock a high amount of inventory to reduce supply costs and price fluctuations, which implies that the benefits of working capital management seem to come mainly from the improvement of operating efficiency rather than reducing the costs of external financing.

Even though this study makes contributions towards a better understanding of working capital management for the Vietnamese firms, it unavoidably has some limitations. The functional of the models used in this research only cover very basic control variables. As the practice of working capital management might change depending on the context, such as on the business cycle, inflation, or on the presence of financial constraints, future research might expand the scope to account for these factors. Besides, this research only covers the data of the Vietnamese listed firms. Future research may enlarge the scale by using a multi-country dataset. This will facilitate comparison and may reveal interesting insights on how firms in different countries manage their working capital. 
[1] Abusayed, B., 2012. Working Capital Management and Firms' Performance in Emerging Markets: The Case of Jordan. International Journal of Managerial Finance, 8(2), pp.155-179.

[2] Almeida, J.R., Eid, Jr, W., 2014. Access to Finance, Working Capital Management and Company Value: Evidence from Brazilian Companies Listed on BM\&FBOVESPA. Journal of Business Research, 67, pp.924-934.

[3] Baños-Caballero, S., García-Teruel, P.J. Martinez-Solano, P., 2014. Working Capital Management, Corporate Performance, and Financial Constraints. Journal of Business Research, 67, pp.332-338.

[4] Blinder, A.S., Maccini, L.J., 1991. The Resurgence of Inventory Research: What Have We Learned?. Journal of Economic Surveys, 5, pp.291-328.

[5] Deloof, M., 2003. Does Working Capital Management Affect Profitability of Belgian Firms?. Journal of Business Finance \& Accounting 30, pp.573-587.

[6] Emery, G., 1984. A Pure Financial Explanation for Trade Credit. Journal of Financial and Quantitative Analysis, 19, pp.271-285.

[7] Enqvist, J., Graham, M., Nikkinen, J., 2014. The Impact of Working Capital Management on Firm Profitability in Different Business Cycle: Evidence from Finland. Research in International Business and Finance, 32, pp.36-49.

[8] Garcia-Teruel, P.J., Martinez-Solano, P., 2007. Effects of Working Capital Management on SME Profitability. International Journal of Managerial Finance, 3(2), pp.164-177.

[9] Gill, A., Biger, N., Mathur, N., 2010. The Relationship Between Working Capital Management and Profitability: Evidence from the United States. Business Economics Journal, 10, pp.1-9.

[10] Hager, H.C., 1976. Cash Management and the Cash Conversion Cycle. Management Accounting, 57(9), pp.19-21.
[11] Jose, M.L., Lancaster, C., Stevens, J.L., 1996. Corporate Return and Cash Conversion Cycles. Journal of Economics and Finance, 20, pp.3346.

[12] Knauer, T., Wohrmann, A., 2013. Working Capital Management and Firm Profitability. Journal of Management Control, 4, pp.77-87.

[13] Kim, Y.H., Chung, K.H., 1990. An Integrated Evaluation of Investment in Inventory and Credit, A Cash Flow Approach. Journal of Business Finance \& Accounting, 17, pp.381-390.

[14] Lazaridis, I., Tryfonidis, D., 2006. Relationship Between Working Capital Management and Profitability of Listed Companies in the Athens Stock Exchange. Journal of Financial Management and Analysis, 19, pp.26-35.

[15] Lee, Y.W., Stowe, J.D., 1993. Product Risk, Asymmetric Information, and Trade Credit, Journal of Financial and Quantitative Analysis, 28, pp.285-300.

[16] Mun, S.G, Jang, S.C., 2015. Working Capital, Cash Holding, and Profitability of Restaurant Firms. International Journal of Hospitality Management, 48, pp.1-11.

[17] Myers, S.C., Majluf, N.S., 1984. Corporate Financing and Investment Decisions When Firms Have Information That Investors Do Not Have. Journal of Financial Economics, 13, pp.187221.

[18] Ng, C.K., Smith, J.K., Smith, R.L., 1999. Evidence on the Determinants of Credit Terms Used in Interfirm Trade. Journal of Finance, 54, pp.1109-1129.

[19] Nguyen, A., Nguyen, T., 2018. Free Cash Flow And Corporate Profitability in Emerging Economies: Empirical Evidence from Vietnam. Economics Bulletin, 38(1), pp.211-220.

[20] O'Brien, R.M., 2007. A Caution Regarding the Rules of Thumb for Variance Inflation Factors. Quality \& Quantity, 41, pp.673-690.

[21] Opler, T., Pinkowitz, L., Stulz, R., Williamson, R., 1999. The Determinants and Implications of Corporate Cash Holdings. Journal of Financial Economics, 53, pp.3-46. 
[22] Petersen, M., Rajan, R., 1997. Trade Credit: Theories and Evidence. Review of Financial Studies, 10, pp.661-691.

[23] Raheman, A., Nasr, M., 2007. Working Capital Management and Profitability: Case of Pakistani Firms. International Review of Business Research Papers, 3, pp.279-300.

[24] Sagan, J., 1955. Toward a Theory of Working Capital Management. Journal of Finance, 10(2), pp.121-129.

[25] Schiff, M., Lieber, Z., 1974. A Model for the Integration of Credit and Inventory Management. Journal of Finance, 29, pp.133-140.
[26] Shin, H.H., Soenen, L., 1998. Efficiency of Working Capital and Corporate Profitability. Financial Practice \& Education, 8, pp.37-45.

[27] The International Monetary Fund, 2017. IMF Country Report No. 17/191: Vietnam, Selected Issues. Retrieved January 15, 2018 from https://www.imf.org/ /media/Files/Publications/ CR/2017/cr17191.ashx

[28] Wang, Y.J., 2002. Liquidity Management, Operating Performance, and Corporate Value: Evidence from Japan and Taiwan. Journal of Multinational Financial Management, 12, pp.159-169. 